\title{
Body Mass Index Change in Females After Short-Time Life Style Intervention Is Not Dependent on the FTO Polymorphisms
}

\author{
D. DLOUHÁ ${ }^{1}$, P. SUCHÁNEK ${ }^{1,2}$, V. LÁNSKÁ ${ }^{1}$, J. A. HUBÁČEK $K^{1,2,3}$ \\ ${ }^{1}$ Institute for Clinical and Experimental Medicine, Prague, Czech Republic, ${ }^{2}$ Centre for \\ Cardiovascular Research, Prague, Czech Republic, ${ }^{3}$ South Bohemia University, Faculty for Public \\ Health and Social Studies, Ceske Budejovice, Czech Republic
}

Received August 20, 2010

Accepted September 21, 2010

On-line October 15, 2010

\begin{abstract}
Summary
Variants within the FTO gene are important determinants of body mass index (BMI), but their role in determination of BMI changes after combined dietary/physical activity intervention is unclear. We have analyzed 107 unrelated overweight non-diabetic Czech females (BMI over $27.5 \mathrm{~kg} / \mathrm{m}^{2}$, age $49.2 \pm 12.3$ years). FTO variants rs17817449 (first intron) and rs17818902 (third intron) were genotyped. The life style modification program (10 weeks) consisted of an age-matched reduction of energy intake and exercise program (aerobic exercise 4 times a week, $60 \mathrm{~min}$ each). The mean BMI before intervention was $32.8 \pm 4.2 \mathrm{~kg} / \mathrm{m}^{2}$ and the mean achieved weight loss was $4.8 \pm 3.5 \mathrm{~kg}(5.3 \pm 3.5 \%$, $\max .-15.5 \mathrm{~kg}, \min .+2.0 \mathrm{~kg}, \mathrm{p}<0.01)$. No significant association between BMI decrease and FTO variants was found. Also waistto-hip ratio, body composition (body fat, water, active tissue), lipid parameters (total, LDL and HDL cholesterol, triglycerides) glucose and hsCRP changes were independent on FTO variants. FTO variants rs17817449 and rs17818902 are not associated with BMI changes after combined short time dietary/physical activity intervention in overweight females.
\end{abstract}

\section{Key words}

Intervention • Diet • Exercise • FTO • Polymorphism • Lipid • Glycaemia

\section{Corresponding author}

Jaroslav A. Hubacek, IKEM-DEM-LMG, Videnska 1958/9, 14021 Prague 4, Czech Republic. Fax: +420 241721666 . E-mail: jahb@ikem.cz
Obesity is a serious health problem worldwide and is associated with increased mortality and morbidity. In combination with unfavorable genetic background, abundant energy intake and low physical activity are major causes of obesity on a population level, but, for example, sleeping habits, non-exercise activity thermogenesis and more stable inside room temperatures could also contribute to the recent increase of obesity prevalence (Hubacek 2009, Adamkova et al. 2009).

Independent genome wide association studies detected variants in the first (rs17817449) (Dina et al. 2007, Scuteri et al. 2007) and third (rs17818902) (Tönjes et al. 2010) intron of the FTO ("fat mass and obesity associated") gene to be (independently) responsible for the BMI determination. The exact function of FTO is unknown so far and the protein has no known similarity to other proteins that could help to predict its function. How FTO gene could affect BMI is not clear - possible role in determination of the energy intake or energy expenditure were suggested, but the achieved results are inconsistent (Cecil et al. 2008, Haupt et al. 2009, Liu et al. 2010, Hasselbalch et al. 2010).

The decrease of the BMI could be in most individuals achieved through restriction of energy intake and enhanced physical activity (both exercise and nonexercise). Nevertheless, the individual responses to lifestyle modification vary (Hainer et al. 2008) and it is clear, that it is partially genetically determined.

We have investigated the influence of FTO rs17817449 and rs17818902 variants on a response to a

PHYSIOLOGICAL RESEARCH • ISSN 0862-8408 (print) • ISSN 1802-9973 (online)

(c) 2011 Institute of Physiology v.v.i., Academy of Sciences of the Czech Republic, Prague, Czech Republic

Fax +420 241062 164, e-mail: physres@biomed.cas.cz, www.biomed.cas.cz/physiolres 
life style changes in 107 overweight (BMI over 27.5 $\mathrm{kg} / \mathrm{m}^{2}$, age $49.2 \pm 12.3$ years), but healthy (without diabetes, thyroid gland disease, any other endocrine disorders, autoimmune diseases, any chronic inflammation, or neoplastic disease) Czech Caucasian females.

The ten weeks life style modification program consisted of equilibrium to the recommended dietary energy intake for the appropriate age and controlled physical activity (for more details see Suchanek et al. 2008, Suchanek et al. 2009).

Dietary intervention was aimed at lowering energy intake (to recommended values), together with decrease in animal fat intake and increase of fruits and vegetables intake. Volunteers participated 3 times weekly in a supervised 1-hour training session at a fitness center, and 3 more sessions per week (cycling, jogging, or brisk walking) were recommended (at least one session was performed by all individual). All these activities included an aerobic exercise component - the participants were supervised (and advised) to sustain heart rate of 115 to 145 beats (according to age) per minute within 60 min of exercise.

The probands have their anthropometrical parameters and blood pressure determined at baseline, after each 2 weeks of intervention and on the end of the study.

Body weight (measured with electronic weight), height (measured with a stadiometer), waist and hip circumferences, were measured by trained staff according the standard protocols. The waist-to-hip ratio (WHR) and BMI were calculated from obtained measurements.

DNA was isolated from frozen EDTA blood by standard method (Miller et al. 1988). FTO variants were analyzed by PCR and restriction analysis. Briefly oligonucleotides 5 ' GGT GAA GAG GAG GAG ATT GTG TAA CTG G and 5`GAA GCC CTG AGA AGT TTA GAG TAA ATT GGG with restriction enzyme AlwNI were used for the genotyping of rs17817449 variant (Hubacek et al. 2008, Hubacek et al. 2009) and oligonucleotides 5' ATC ATT CTG AAA ACA GAT CTG ACT GG and 5'ATG GGT TTA TGA ACC ATA GGA AAG AAT CGA G with restriction enzyme BsaI were used for the genotyping of rs17818902 variant.

The ethics committee of the Institute approved the study and all participants signed their informed consent. ANOVA for repeated measures was used in order to evaluate the statistical significance of the differences between before and after study tests. Because of the multiple testing, $\mathrm{P}$ value less than 0.01 was considered to be significant. All data are presented as means \pm SD.

There was no evidence for deviation of genotype frequencies from Hardy-Weinberg equilibrium. In comparison to the general populations (Hubacek et al. 2008, Dlouha et al. 2010) between obese females were nonsignificantly more carriers of the obesity associated GG genotypes (22.4\% vs. $18.8 \%$, for rs 17817449 and $5.8 \%$ vs. $4.5 \%$ for rs 17818902 ).

All subjects completed the follow-up during ten weeks, with the mean weight loss of $4.8 \pm 3.5 \mathrm{~kg}$ $(5.3 \pm 3.5 \%)$, with minimum "loss" of $+2 \mathrm{~kg}$, and maximum loss of $-15.5 \mathrm{~kg}$.

No significant association between BMI changes and FTO rs17817449 and rs17818902 genotypes was found (Figure 1).
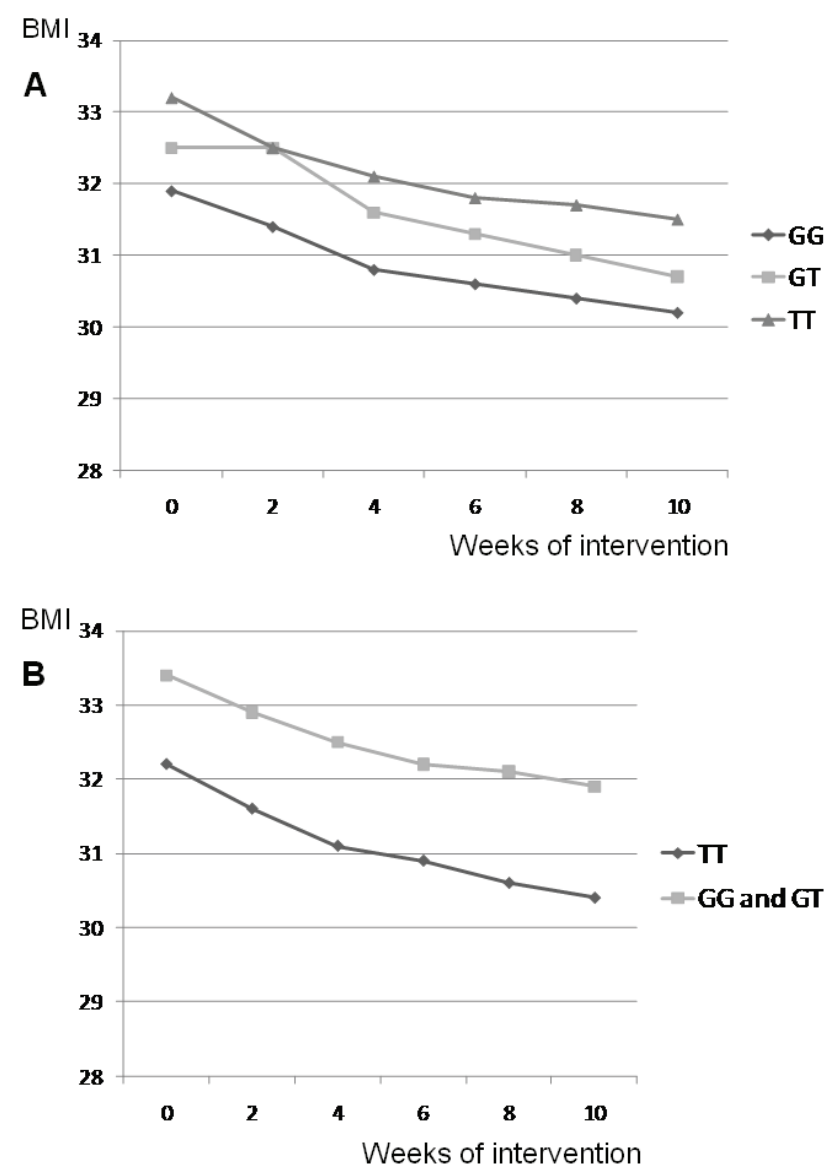

Fig. 1. BMI decrease according the FTO genotypes (A for rs17817449 and $\mathbf{B}$ for rs1788902). (In the figure just means are given, SD were, according the weeks of intervention $\pm 3.9 ; \pm 3.8$; $\pm 3.7 ; \pm 3.7 ; \pm 3.7 ; \pm 3.7$; for $T$ and $\pm 4.6 ; \pm 4.5 ; \pm 4.5 ; \pm 4.3$; $\pm 4.4 ; \pm 4.3$; for $\mathrm{G}$ allele carriers of the rs 1788902 SNP and for rs17817449 than for $\Pi \pm 3.2 ; \pm 3.0 ; \pm 2.9 ; \pm 2.9 ; \pm 3.1 ; \pm 3.0$; for TG $\pm 3.8 ; \pm 3.8 ; \pm 3.6 ; \pm 3.7 ; \pm 3.7 ; \pm 3.8$; and finally for GG \pm 5.3 ; $\pm 5.2 ; \pm 5.1 ; \pm 4.9 ; \pm 5.0 ; \pm 4.7)$. 
FTO gene variants had also no influence on waist, hip, body weight, waist to hip ratio, body composition (body fat, water, active tissue), lipid parameters (total, LDL and HDL cholesterol, triglycerides) glucose and hsCRP values development through the intervention (data not shown in details).

After ten weeks of lifestyle modification, consisting of at least 4 units of exercise per week and changing of dietary habits, we have observed significant decrease in BMI and body weight in all females. Further, our results confirmed a large interindividual variability in response to the applied lifestyle modification. Most importantly the difference between the maximal and minimal body weight change was $17.5 \mathrm{~kg}$. As the exercise training was three times a week performed under supervision at fitness centre, we suppose, that the differences likely reflect the different genetic predisposition than failure in the adherence to the dietary regimen and physical activity program.

So far, just interventions in children (Rendo et al. 2009), leads to the significant decrease of BMI, which was modulated by the FTO genotype and carriers of the obesity related genotype profit more from the intervention. In contrast, some another recent studies on differently defined individuals [children and adults (Müller et al. 2008) and diabetic patients (Lappalainen et al. 2009), the exact protocols used there for the duration and style of intervention differ from our study] also failed to report significant effect of the FTO variant on intervention dependent BMI changes. All these studies have analyzed first intron FTO variants (rs17817449 is in almost complete linkage disequilibrium with all of them) only.

Our study have at first time analyzed the role of FTO rs17818902 variation in third intron on life style modification associated changes on anthropometric and biochemical parameters in females, however, also with negative results.

In conclusion, in overweight healthy females, FTO gene variants in first (rs17817449) and third (rs17818902) intron have no effect on BMI, body composition and lipid parameters development over time of short lifestyle intervention. Most likely, despite the important role in obesity development per se, FTO variants have no effect on life style induced profitable changes in anthropometric and biochemical parameters.

\section{Conflict of Interest}

There is no conflict of interest.

\section{Acknowledgements}

This work was supported by Institute for Clinical and Experimental Medicine (MZO 00023001) and by grants No. 1M0510 (Ministry of Youth, Sport and Education of the Czech Republic) and NS 10513-3/2009 (IGA, Ministry of Health of the Czech Republic).

\section{References}

ADÁMKOVÁ V, HUBÁCEK JA, LÁNSKÁ V, VRABLÍK M, KRÁLOVÁ LESNÁ I, SUCHÁNEK P, ZIMMELOVÁ P, VELEMINSKÝ M: Association between duration of the sleep and body weight. Physiol Res 58 (Suppl 1): S27-S31, 2009.

CECIL JE, TAVENDALE R, WATT P, HETHERINGTON MM, PALMER CN: An obesity-associated FTO gene variant and increased energy intake in children. $N$ Engl J Med 359: 2558-2566, 2008.

DINA C, MEYRE D, GALLINA S, DURAND E, KÖRNER A, JACOBSON P, CARLSSON LM, KIESS W, VATIN V, LECOEUR C, DELPLANQUE J, VAILLANT E, PATTOU F, RUIZ J, WEILL J, LEVYMARCHAL C, HORBER F, POTOCZNA N, HERCBERG S, LE STUNFF C, BOUGNÈRES P, KOVACS P, MARRE M, BALKAU B, CAUCHI S, CHÈVRE JC, FROGUEL P: Variation in FTO contributes to childhood obesity and severe adult obesity. Nat Genet 39: 724-726, 2007. Corrigendum in: Nat Genet 39: 1285, 2007.

DLOUHA D, ADAMKOVA V, LANSKA V, HUBACEK JA: Lack of association between a new tag SNP in the FTO gene and BMI in Czech Slavonic population. Eur J Hum Genet 18: 1274, 2010.

HAINER V, ZAMRAZILOVÁ H, SPÁLOVÁ J, HAINEROVÁ I, KUNESOVÁ M, ALDHOON B, BENDLOVÁ B: Role of hereditary factors in weight loss and its maintenance. Physiol Res 57 (Suppl 1): S1-S15, 2008.

HASSELBALCH AL, ANGQUIST L, CHRISTIANSEN L, HEITMANN BL, KYVIK KO, SØRENSEN TI: A variant in the fat mass and obesity-associated gene (FTO) and variants near the melanocortin-4 receptor gene (MC4R) do not influence dietary intake. $J$ Nutr 140: 831-834, 2010. 
HAUPT A, THAMER C, STAIGER H, TSCHRITTER O, KIRCHHOFF K, MACHICAO F, HÄRING HU, STEFAN N, FRITSCHE A: Variation in the FTO gene influences food intake but not energy expenditure. Exp Clin Endocrinol Diabetes 117: 194-197, 2009.

HUBACEK JA, BOHUSLAVOVA R, KUTHANOVA L, KUBINOVA R, PEASEY A, PIKHART H, MARMOT MG, BOBAK M: The FTO gene and obesity in a large Eastern European population sample: the HAPIEE study. Obesity (Silver Spring) 16: 2764-2766, 2008.

HUBACEK JA, PITHA J, ADAMKOVA V, LANSKA V, POLEDNE R: A common variant in the FTO gene is associated with body mass index in males and postmenopausal females but not in premenopausal females. Czech post-MONICA and 3PMFs studies. Clin Chem Lab Med 47: 387-390, 2009.

HUBACEK JA: Eat less and exercise more - is it really enough to knock down the obesity pandemia? Physiol Res $\mathbf{5 8}$ (Suppl 1): S1-S6, 2009.

LAPPALAINEN TJ, TOLPPANEN AM, KOLEHMAINEN M, SCHWAB U, LINDSTRÖM J, TUOMILEHTO J, PULKKINEN L, ERIKSSON JG, LAAKSO M, GYLLING H, UUSITUPA M; FINNISH DIABETES PREVENTION STUDY GROUP: The common variant in the FTO gene did not modify the effect of lifestyle changes on body weight: the Finnish Diabetes Prevention Study. Obesity (Silver Spring) 17: 832-836, 2009.

LIU G, ZHU H, LAGOU V, GUTIN B, STALLMANN-JORGENSEN IS, TREIBER FA, DONG Y, SNIEDER H: FTO variant rs9939609 is associated with body mass index and waist circumference, but not with energy intake or physical activity in European- and African- American youth. BMC Med Genet 11: 57, 2010.

MILLER SA, DYKES DD, POLESKY HF: A simple salting out procedure for DNA extraction from human nucleated cells. Nucleic Acid Res 16: 1215, 1988.

MÜLLER TD, HINNEY A, SCHERAG A, NGUYEN TT, SCHREINER F, SCHÄFER H, HEBEBRAND J, ROTH CL, REINEHR T: 'Fat mass and obesity associated' gene (FTO): no significant association of variant rs9939609 with weight loss in a lifestyle intervention and lipid metabolism markers in German obese children and adolescents. BMC Med Genet 9: 85, 2008.

RENDO T, MOLERES A, MARTI DEL MORAL A: Effects of the FTO gene on lifestyle intervention studies in children. Obes Facts 2: 393-399, 2009.

SCUTERI A, SANNA S, CHEN WM, UDA M, ALBAI G, STRAIT J, NAJJAR S, NAGARAJA R, ORRÚ M, USALA G, DEI M, LAI S, MASCHIO A, BUSONERO F, MULAS A, EHRET GB, FINK AA, WEDER AB, COOPER RS, GALAN P, CHAKRAVARTI A, SCHLESSINGER D, CAO A, LAKATTA E, ABECASIS GR: Genome-wide association scan shows genetic variants in the FTO gene are associated with obesity-related traits. PLoS Genet 3: e115, 2007.

SUCHÁNEK P, HUBACEK JA, KRÁLOVÁ LESNÁ I, PINEKEROVÁ V, ADÁMKOVÁ V: Actigenetic of ACE gene polymorphism in Czech obese sedentary females. Physiol Res 58 (Suppl 1): S47-S52, 2009.

SUCHANEK P, LORENZOVA A, POLEDNE R, HUBACEK JA: Changes of plasma lipids during weight reduction in females depends on APOA5 variants. Ann Nutr Metab 53: 104-108, 2008.

TÖNJES A, ZEGGINI E, KOVACS P, BÖTTCHER Y, SCHLEINITZ D, DIETRICH K, MORRIS AP, ENIGK B, RAYNER NW, KORIATH M, ESZLINGER M, KEMPPINEN A, PROKOPENKO I, HOFFMANN K, TEUPSER D, THIERY J, KROHN K, MCCARTHY MI, STUMVOLL M: Association of FTO variants with BMI and fat mass in the self-contained population of Sorbs in Germany. Eur J Hum Genet 18: 104-110, 2010. 